\title{
Adapting Shipping Containers as Temporary Shelters in Terms of Recycling, Sustainability and Green Architecture. Reuse as Accommodation in Egypt.
}

\author{
Rania El Messeidy \\ Lecturer, Department of Architecture, Faculty of Engineering, October University for Modern \\ Sciences and Arts (MSA) University, $6^{\text {th }}$ of October, Cairo, Egypt
}

\begin{abstract}
Cargo containers have grown in architecture around the world. They are durable, adaptable, have light weight, 'low cost' and ease of stacking, taking many forms such as sculpture, homes, housing, hotels, however, most of their remittances are related to temporary housing needs, such as emergency shelters and mobile shelters. Repurposing cargo containers into structures is a reasonable sustainable practice because of most of the structure originating from reused materials, They have a smaller carbon footprint and create less landfill, also their environmental impact is low in comparison to traditional buildings made with brick and reinforced concrete structure, they require a short time to be erected with an advantage of mobility in case of future extension or moving these structures to different areas or including additional areas or volumes. The standards dimensions of ISO shipping containers make them excellent modular units which have the auxiliary capacity and plan parameters to create standard settlement units in an assortment of ways, it is a complete standard accommodation with its intrinsic quality, waterproof nature and availability, making it an exemplary structural component. Although shipping containers could be one of the solutions of emergency and mobile shelters and not the optimum one,
\end{abstract}


it has less appeal than other building materials which require some adaptation to meet human and user needs and fit in with the context. Shipping containers could be also responsive on community level and provide temporary solutions to a particular shortage. This paper aims to provide an adapting of shipping containers as sustainable, green and recycled solution not only as Architecture but also as collecting and gathering units on site. As an effective study, the paper will examine the adaptation of shipping containers in various international projects in order to highlight the possibility of using Containers architecture in temporary accommodation shelters. This paper therefore, will introduce a new approach of reusing shipping containers as shelters solutions not in a matter of spaces as much as attention to human and community needs within a framework of urban compatibility. One of the paper results is to have a model in the way it could be in the site.

Keywords: Cargotecture, Shipping Containers, Shelters, Temporary accommodation, Recycling, Sustainability.

\section{Introduction}

Using shipping containers as a building materials is not new new, as Paul Sawerys recognizes in his book 'Intermodel Shipping Container Small Steel Buildings', distributed in 2005. However, most shipping containers are used for temporary housing needs. ISO shipping containers have been utilized in financially discouraged nations and they have demonstrated their adaptability, where there is an incredible social need, possibly low aptitudes, and absence of building materials. (1). Due to the majority of the structure coming from recycled materials, repurposing cargo containers into homes is a sustainable construction practice (2). Adapting shipping containers for design reasons for existing isn't restricted to particular sorts of structures but from little private homes to high rises. Cargo containers Cargo containers offer unlimited combinations according to their pattern and are utilized for a wide range of structures, social, local, and business. The Cargo containers goes above and beyond contrasted with conventional stone work, with longer cantilevers starting from its auxiliary arrangement. As a generally undiscovered pattern, Cargo containers can be opened into a structure, and this mix makes another advantageous interaction. (3)

\section{What is a Cargotecture?}

Cargotecture could be defined as 'The building system of using ISO-dimensions elements, cargo container conversions or ISO-dimension prefabricated modules, into a dwelling, shop, school or office space which would be shippable if ever located' Joel Egan of Robert Humble / Hybrid Architects 2004 (1). Cargotecture is that type of architecture that is 
generally characterized by the reuse of steel shipping containers as a structural element and architectural envelope that can host a specific function or a human activity, a blend of conventional architecture and containers. Using shipping containers require short time to erect buildings, with future possibilities of moving these buildings to other locations or adding extra spaces or volumes. (4)

The noun "container" derives from the verb "to contain," which determines the action of constipation or circumference. Regulation clarifies how a life form or sorted out framework supports itself by isolating off from its general surroundings. Container particulars inner capacities, balances relations with the outside, and regulates the possibilities of growth, regeneration and overcoming (5). The cargo container is known by numerous names; when utilized for transportation it is essentially alluded to as a "shipping container", yet can likewise be called an "ISO container", "Conex box" or cargo container." When utilized as a development material, be that as it may, it is alluded to as a Intermodal Steel Building Unit (ISBU). Cargo containers are built from enduring steel which incorporates alloying components that influence the materials consumption process. Enduring steel frames an internal layer that ensures the safe of the steel. (2) Yet, these same characteristics can be of high value in smaller innovative settings and projects demanding temporary occupation and deployment. When it comes to living architecture; the cargo container's structure accommodates additional weight loads; the walls and roofs possess opportunities for design innovation; and the entire unit is mobile. Exploring these attributes may broaden the adaptation of shipping containers beyond permanent occupancy. (6) As reused elements, shipping compartments support manageable building and living practices Cargo containers promote sustainable construction and life practices as they are reused materials. Limited boxes, they request refinements, extensions and connections. In unconventional places, the mobility of urban containers is questioning the gap between private and public property, as well as the separation of interiors, landscapes and infrastructure. (5)

\subsection{Shipping Containers Characteristics}

A shipping container have a suitable strength to support large cargo transits and stowage, it is a steel frame-usually cuboid. The containers have various types, varying from refillable to universally standards. (7)

\section{A. Specifications and Dimensions}

Shipping container is made of 6 planes, floor, top, and four sides, these sides are strong enough to tolerate loads, or pressures that may occur during the transportation process. Shipping containers have posts and enforcements in the corners, or intersections of these 
planes (sides), or below the floor, or above the top. (4) Table 1, define standard cargo container dimensions as shown below.

Table 1. Standard cargo container dimensions. Ref. (8)

\begin{tabular}{|c|c|c|c|c|c|c|c|}
\hline \multirow{2}{*}{\multicolumn{2}{|c|}{ Dimensions }} & \multicolumn{2}{|c|}{\begin{tabular}{|c|} 
Container \\
$20^{\prime}\left(20^{\prime} \mathrm{DC}\right)$ \\
\end{tabular}} & \multicolumn{2}{|c|}{\begin{tabular}{|l|} 
40' standard \\
(40'DC)
\end{tabular}} & \multicolumn{2}{|c|}{\begin{tabular}{|l|} 
40' high \\
(40'HC) \\
\end{tabular}} \\
\hline & & imperial & metric & imperial & metric & imperial & metric \\
\hline \multirow{3}{*}{ External } & Length & $19^{\prime} 10,5^{\prime \prime}$ & $\begin{array}{c}6,058 \\
\mathrm{~m}\end{array}$ & $40^{\prime}$ & $\begin{array}{c}12,192 \\
\mathrm{~m}\end{array}$ & $40^{\prime}$ & $12,192 \mathrm{~m}$ \\
\hline & Width & $8^{\prime}$ & $\begin{array}{c}2,438 \\
m\end{array}$ & $8^{\prime}$ & $\begin{array}{c}2,438 \\
m\end{array}$ & $8^{\prime}$ & $2,438 \mathrm{~m}$ \\
\hline & Height & 8'6" & $\begin{array}{c}2,591 \\
\mathrm{~m}\end{array}$ & 8'6" & $\begin{array}{c}2,591 \\
\mathrm{~m}\end{array}$ & 9'6" & $2,896 \mathrm{~m}$ \\
\hline \multirow{3}{*}{$\begin{array}{l}\text { Internal } \\
(\mathrm{min})\end{array}$} & Length & & $\begin{array}{c}5,867 \\
\mathrm{~m}\end{array}$ & & \begin{tabular}{|c}
11,998 \\
$\mathrm{~m}$
\end{tabular} & & $\begin{array}{c}11,998 \\
\mathrm{~m}\end{array}$ \\
\hline & Width & & $\begin{array}{c}2,330 \\
\mathrm{~m}\end{array}$ & & \begin{tabular}{|c|c}
2,330 \\
$\mathrm{~m}$ \\
\end{tabular} & & $2,330 \mathrm{~m}$ \\
\hline & Height & & $\begin{array}{c}2,350 \\
\mathrm{~m}\end{array}$ & & $\begin{array}{c}2,350 \\
\mathrm{~m}\end{array}$ & & $2,655 \mathrm{~m}$ \\
\hline \multicolumn{2}{|c|}{ Gross mass } & $24000 \mathrm{~kg}$ & $\begin{array}{c}52900 \\
\mathrm{lb}\end{array}$ & $30480 \mathrm{~kg}$ & $\begin{array}{c}67200 \\
\mathrm{lb}\end{array}$ & $\begin{array}{c}30480 \\
\mathrm{~kg}\end{array}$ & $67200 \mathrm{lb}$ \\
\hline
\end{tabular}

\section{B. Considerations of Stacking}

Based on previous studies, stacked shipping containers could reach six units and 12 units if they are empty. However, some reviewers have stated that there is no limit to the accumulation of vertical shipping containers but as an example of real estate buildings, it was concluded that stacking varies from one to nine floors. Taking in consideration the calculation required for each case and appropriate reinforcement at the necessary points. (3)

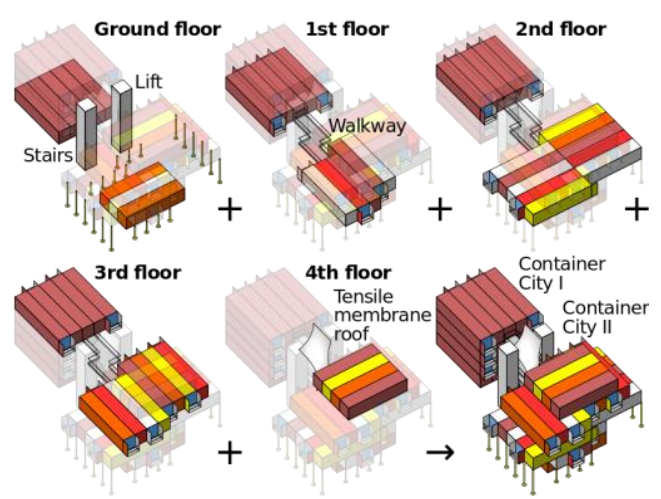

London shipping containers city. Ref. (9) 


\section{Structure and Design}

Most shipping containers are made of ridged steel or layered steel, guaranteeing high erosion obstruction. The construction incorporates the utilization of trapezoidal metal sheets to shape the dividers, rooftop, edges of the case and work to help the wooden floor. The thickness of the trapezoidal steel sheets of the dividers and the rooftop is $2 \mathrm{~mm}$, and the depth of the layered steel sheets is in the range of 25 and 30 and $50 \mathrm{~mm}$, contingent upon the model of the shipping containers and the surface. The angles are designed in the form of unbending components to help the containers and permit association between containers. The door is situated on one of the littler sides. Standard ground surface in ISO shipping containers is the thickness of marine plywood grade $28 \mathrm{~mm} \mathrm{(3).}$

\section{Internal and External Thermal Insulation}

Different types of thermal insulation are suitable for metal structures, such as spray foam, solid insulation panels, blanket insulation such as rock wool and fiberglass, fibers such as mineral wool, and environmentally friendly insulation materials such as wool, recycled cotton, clay and straw. Outside protection is superior to inside for two reasons: a) Because internal insulation reduces internal dimensions of the container, B) is that outer protection enables the designer to take full favorable position of the warm restrictions of the container. Regarding cost, shipping containers themselves are water resistant. In this manner, outside warm protection requires the addition of water insulation, bringing about extra expenses. . Likewise, stacking of containers reduces the requirement for thermal insulation. (3)

\section{Containers in Urban Design}

Two important moments can highlight using shipping containers in urban. Two important moments can highlight the depth of the container. The first originated in late modernity, from about the 1960s to the early 1970s, when the urbanization of emerging containers, embodied by the Japanese Metabolists (Architectural movement 1950s- 1960s, Japan) and the British group Archigram (Architectural group formed in the 1960s, based at the Architectural Association, London), looked to separate the mass and strategy for those immense and repetitive building gatherings which were then reengineering urban presence.

Multiplying mechanical frameworks - from elevators to electrical wires - were incorporated into massive stabilized foundations reinforced by individual container units (and apparently portable). At this point, around the new millennium, a second period of urbanization of containers, including the marvel of DIY, deviated into plan position more tuned in to our time of native support, worldwide business and scaled down innovation. Rather than endeavoring to build a perfect and independent urban gathering, container 
urbanisms are figuring out how to make utilization of existing framework and neglected modern curios. (5) Between 1960 and 1962, the "Cities in the Air" was derived from Arata Isozaki of Friedman's ideas, as well as the division of Louis Kahn between service areas and servers and Kenzo Tang's metabolist proposal to reach the city as a platform to reach across the Tokyo Bay. Isozaki laid the 40-foot-high infrastructure at about 275 feet, raising his utopia above the congested existing city. The towers reinforced the service pipes and turned into diamond-shaped spaces where units populated with mass were attached. The lateral vertical elements, joined horizontally by the trusses, absorbed expressive mobile lifestyles - container units swirling like leaves in the winds of change. (10)

Moshe Safdie built "Habitat" at Expo 67, in Montreal, He built 354 standard units up to 12 floors high, and collected them in 15 different configurations. Ready-made concrete units serve as infrastructure. Each unit supports the other units, and its roofs act as gardens, balconies and passage corridors. Habitat's complex shape emerges from the accumulation of interlocking of units that, such as stone blocks or bricks, which show how each urban group can be formed from diverse parts into a range of individual perspectives and manifestations.

Five years later, Paul Rudolph's take on a mobile home park, the "Oriental Masonic Gardens", located in New Haven. The 148 wooden containers were transported on trucks to the site from a factory in Maryland; although lengths vary between 27 and 51 feet, the width is a standard 12 feet. (5) Habitat's proposals around the world have come to nothing, Kisho Kurokawa's single Nakagin "Capsule Tower" (1972) in Tokyo was one of a few achievements in many of the plug-in proposals.

In 2002 LOT-EK unveiled the "Mobile Dwelling Unit" impressed by Andrea Zittel who constructed "A-Z West" (1990s) in the California desert and Wes Jones's proposal the "Technological Cabins" for several California mountain getaways in (1995s). Hacking out a few openings for windows, sawing a few creases with the goal that surfaces could be pulled separated, the MDU could be specifically opened, to be sure expelled, into whatever site it was put into. The MDU could likewise transform into a normal, along these lines agreeing with the idea of the shipping container and additionally the requirements of an expanding number of individuals who spend immense bits of their lives in a hurry; So LOT-EK has expanded the idea of becoming a vision of the construction of tall structures in urban areas. (11)

Consider Nicholas Lacey and Accomplices' "Container City I and II" (1999-2000, 2005), it was a powerful perplexing of artist studios situated at Trinity Buoy Wharf in London; the designers used two sorts of 40 -foot units - 45 boxes in all - collected around a common vertical center and associated by bridges (12). Four to five were exhibited in red, 
yellow, light blue and dark colors opened through alcove windows and balconies with sliding glass doors, unevenly separated and reinforced by thin steel columns. Through more than 3,500 brightly colored cargo containers, MVRDV was created for Container City (2002), a visual style similar to that of video games for what would literally be around.(13) Beginning in 2007 and advancing to 2012, the "Tokyo Plan Week" transferred annual cargo containers to demonstrate crafted by architects, organizations and design schools. In 2010, at a temporary event of the developer Macro-Sea, parts of Park Avenue in New York were temporarily closed to the cars, and three previous containers became a collection of the "Pop-Up Swimming Pool" prompted adjoining picnics on the solid and a bike slalom course.

A year later, Los Container was established in Cholula, Mexico, and it was a semi-sporadic urban neighborhood with around 50 reusable containers, a wonderful repainting that was finished with other materials such as plastic pipes and jars; Restaurants, commercial establishments and open air yards, and has turned into a social occasion put for displays and festivities. (5)

The two moments of container urbanism, at last, imagine distinctively the city's functional and geographic limits. Late present day holder urbanism was given to monstrous projects replacing the current city, however, was limited by the concept of city as a separate geographical entity. Explain our understanding of the size of the city and its operations to match economic flows and global information by proposing propose minimally invasive surgical procedures. In 2012, Douglas Burnham is founder and principal of envelope Architecture + Design (Envelope A+D) designed and developed "Proxy" a temporary open space experiment activating two vacant development parcels in the heart of San Francisco's Hayes Valley neighborhood.

Proxy repurposes about dozens of shipping containers to accommodate fewer outdoor businesses. It contained openings, overhangs, and trimmings naturally developing as handles, hooks and bolting bar, hosting a dress boutique, beer garden, coffee bistro, icecream parlor and bike rental business in eight-by-twenty-foot containers and in addition cooking, cleaning and storerooms and set of bathrooms. (14). 
Table 2. Containers in Urban Design. Ref. (5), edit by the researcher

\begin{tabular}{|l|l|l|}
\hline $\begin{array}{l}\text { Arata Isozaki, Cities } \\
\text { in the Air, 1960. }\end{array}$ & $\begin{array}{l}\text { LOT-EK, Mobile } \\
\text { Dwelling Unit, 2003. }\end{array}$ \\
\hline $\begin{array}{l}\text { Moshe } \\
\text { Safdie, Habitat 67, } \\
\text { Montreal, 1967. }\end{array}$ & $\begin{array}{l}\text { Nicholas Lacey \& } \\
\text { Partners, Container } \\
\text { City II, London, } \\
\text { 2005. }\end{array}$ \\
\hline $\begin{array}{l}\text { Paul } \\
\text { Rudolph, Oriental } \\
\text { Masonic Gardens, } \\
\text { New Haven, } \\
\text { Connecticut, 1968- } \\
\text { 71. }\end{array}$ & $\begin{array}{l}\text { Los Containers, } \\
\text { Cholula, Mexico, }\end{array}$ \\
\hline $\begin{array}{l}\text { 2009. } \\
\text { Kisho }\end{array}$ & & \\
Kurokawa, Nakagin \\
Capsule Tower, \\
Tokyo.
\end{tabular}

\section{Ecosystem in Shipping Containers as friendly Option}

Shipping containers a high quality product coming from recycling process which could be considered a kind of sustainability. Cargo buildings are contributed in sustainability as they are adapted, recycled materials which help reducing embodied energy, the effects of carbon and greenhouse gas emissions. The adaptation of shipping containers for architectural uses 
help saving the energy consumed when they are melted and cut to be converted. Additionally, Cargo buildings, could be provided by environmental treatment and green technologies like traditional buildings. As for lifecycle, Cargo buildings have a smaller environmental impact.

The low profile of the container is a big advantage in a lot of factors. Material cost, heat distribution and energy usage are affected by interior space. Ecologically, a refurbished container is a more eco-friendly solution according to some specialists because less wood is cut in order to create this type of living space. Shipping containers also are not a rarity and most of the time become unused after a few voyages around the world. (3) Living roofs and walls are currently being incorporated into re-used shipping containers when they are converted to small houses, offices, and shelters. A project at the 2011 Chelsea Flower Show demonstrated a green roof's potential to supply ecosystem services to a garden shed made of a refurbished container. (6)
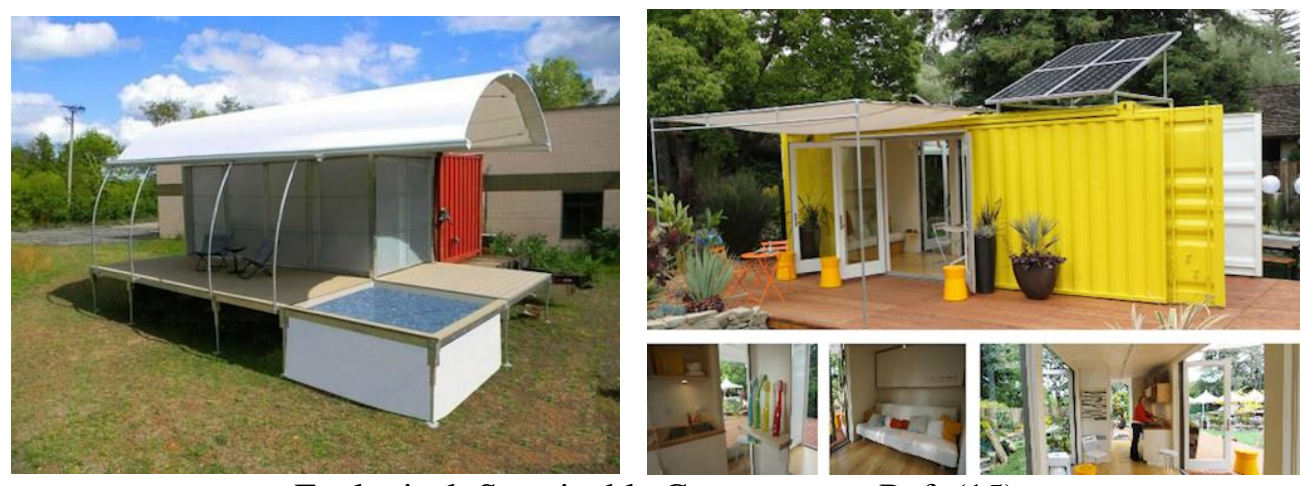

Ecological, Sustainable Cargotecture. Ref. (15)

\section{Case Studies:}

The case studies have been selected for several reasons:

a) They are universal.

b) They have been used and tested and can therefore be evaluated.

c) These projects dealt with shipping containers on the level of Architecture whether using a single unit or in an assembling adaptation.

In order to highlight the lessons have been learned from these projects, table 3 is representing of the analysis and lessons learned from these case studies as shown below: 
Table 3. Case studies and Lessons learned. Ref. The auther

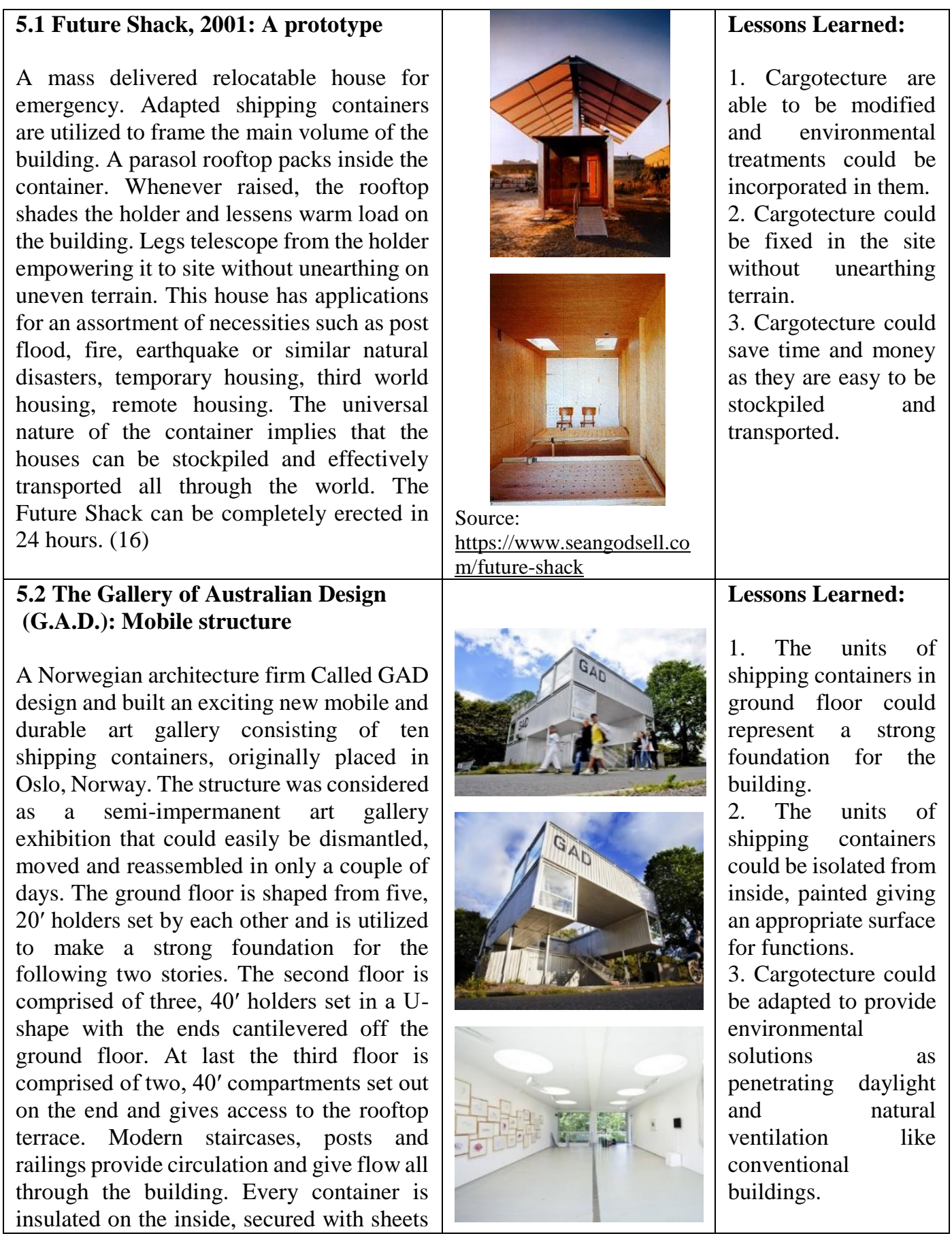




\begin{tabular}{|c|c|c|}
\hline $\begin{array}{l}\text { of plywood and sheetrock (GWB) and } \\
\text { painted all white to give a decent surface for } \\
\text { showing artwork. The ends of the containers } \\
\text { highlight floor-to-roof glass windows, } \\
\text { round opening windows and some } \\
\text { component round skylights to penetrate the } \\
\text { space with normal light. (17) }\end{array}$ & & \\
\hline $\begin{array}{l}5.3 \text { Tempohousing - Keetwonen: Mega } \\
\text { Project } \\
\text { Keetwonen comprises of } 1,000 \text { container } \\
\text { units bolted together and divided into } 12 \\
\text { different buildings stacked up to five levels } \\
\text { high. It contains a laundry, a small market, } \\
\text { a bicycle fix shop and an eatery spread over } \\
\text { a land region of about } 4.5 \text { sections of land } \\
{[1.8 \text { hectares ( } 300 \text { by } 60 \text { meters)]. On the }} \\
\text { site at a pace of } 20 \text { to } 25 \text { units a day the } \\
\text { converted container units were placed. } \\
\text { Containers are welded steel-framed } \\
\text { modules, seismically stable. Containers can } \\
\text { hold over } 67,000 \text { pounds and bear loads of } \\
\text { over } 210 \text { pounds per square foot. Each unit } \\
\text { has a private such as balcony, or garden if } \\
\text { the unit is on the ground floor. In between } \\
\text { the buildings, there are courtyards between } \\
\text { buildings formed by walkways, bridges and } \\
\text { stairways, which also provide bike storage. } \\
\text { Covered, but unenclosed, galleries and } \\
\text { stairways connect the units. (18) }\end{array}$ & Source: (18), (19) & $\begin{array}{l}\text { Lessons Learned: } \\
\text { 1. Cargotecture could } \\
\text { be adapted to provide } \\
\text { a large scale projects } \\
\text { using about } 1000 \\
\text { units and providing } \\
\text { various services. } \\
2 . \text { Depending on } \\
\text { design, cargotecture } \\
\text { could provide } \\
\text { solutions for human } \\
\text { needs such as: } \\
\text { privacy, connection, } \\
\text { also could be } \\
\text { responsive on the } \\
\text { urban scale providing: } \\
\text { courtyards, } \\
\text { walkways, gardens, } \\
\text { shaded areas. }\end{array}$ \\
\hline
\end{tabular}

\section{Sustainable Cargotecture in Egypt, Qubix Company}

As for the Egyptian case, Qubix was the only case founded representing Cargotecture in Egypt. Qubix, is a company founded by Youssef Farag and Karim Rafla an Egyptian design duo, who has begun re-purposing old steel shipping containers, transforming them into living spaces, shops and restaurants. (20) Qubix, with a major in with a noteworthy in Worldwide Business Management in 2014, began their innovative work and preparing toward the beginning of Walk 2016. They are a group of planners, developers and specialists and chose to bounce in the profound end and attempt to construct a Hydraulic System Resto-Container that they found in Canada that was being sold for US \$270,000. 
A couple of months after the fact, their preparation and their model item was finished which they move for EGP 190,000-over 90\% less expensive than the Canadian form. (21)

\subsection{Private Home, Beni Suef, Egypt}

The house flaunts two full restrooms, a main room, living room and completely prepared kitchen - all cooled, with hardwood flooring - even a housetop deck, floor-to-roof glass paneling on one divider and a sunshade-hung yard that offer incredible perspectives on the encompassing landscape. As the designer mentioned, it is environmentally friendly, costefficient, sustainable, quicker to manufacture, more grounded as a structure and it's versatile to any industry.

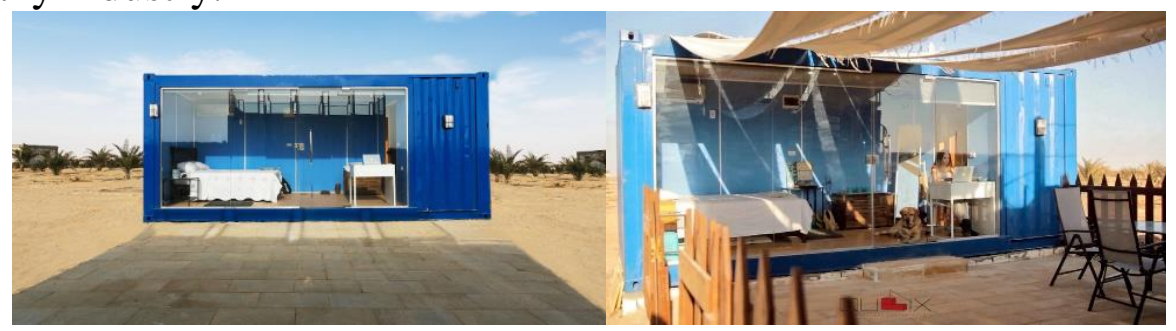

The Beni Suef Home. Ref. (23)

The first phase of design, the designer handle the requirements of the customers and comprehend what the container will be utilized for. The second stage is the advancement stage, they begin to build up the foundation and give warm protection, electric wiring, pipes and sound protection. Amid the second stage, they introduce climate control systems, lightning and the containers are double-layered to insulate humidity. The last stage is that they convey the last containers and hand them to their customers. (23)

\section{A proposed design Models}

Table. 4 comprises different design models proposed in a way of providing adapting of shipping containers as:

1. A new approach for shelters solutions not in a matter of spaces as much as attention to human and community needs within a framework of urban compatibility.

2. A solution, not only as an Architecture but also as a way of assembling and gathering units on site. 
Table 4. Proposed Design Model. Ref. The auther

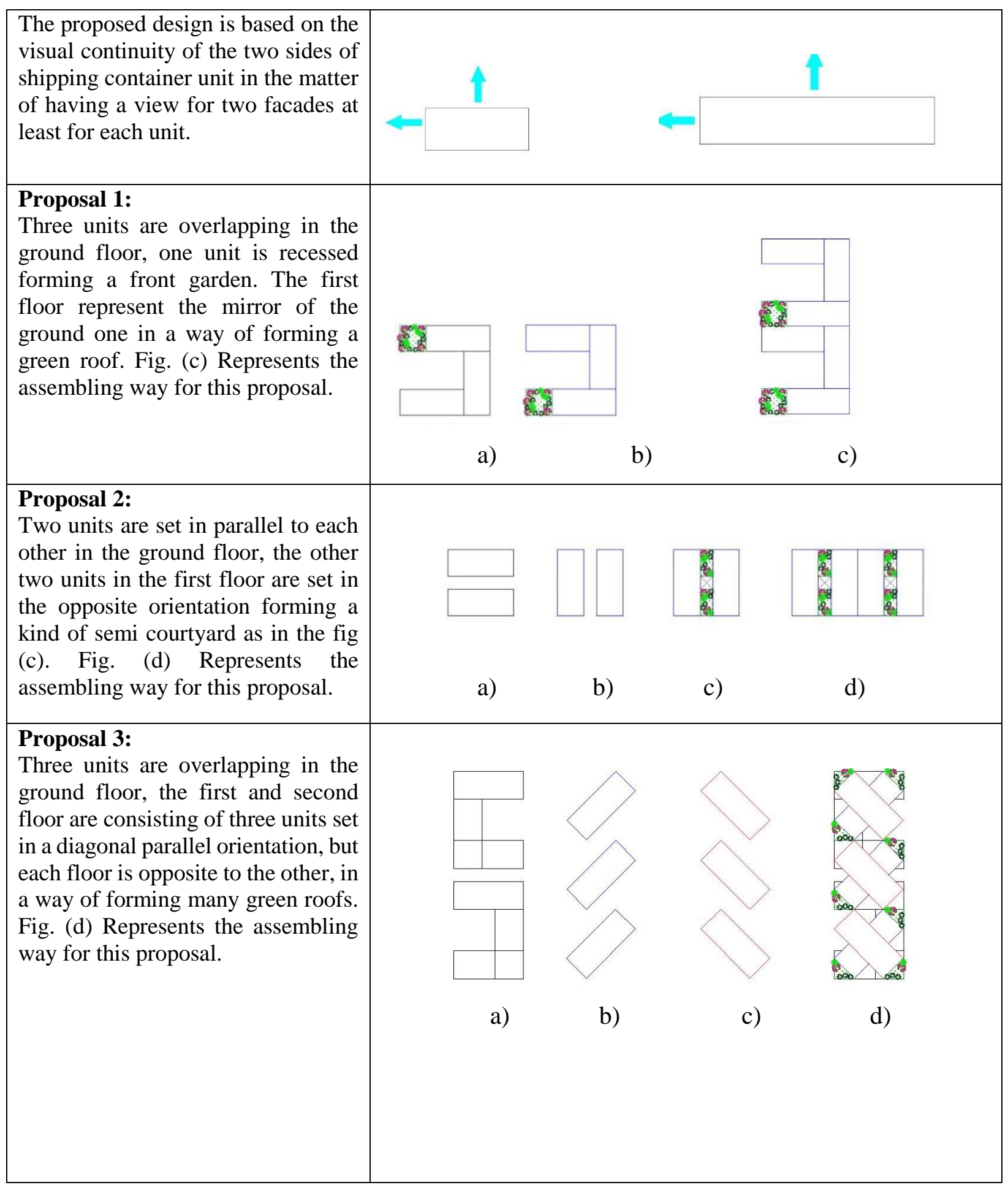




\section{Proposal 4:}

The model is consisting of four units, each two units are set in a perpendicular orientation forming two units opposite to each other. The second floor represents the mirror of the ground floor in the way of forming two green roof and a courtyard. Fig. (d) Represents a assembling way for this proposal.

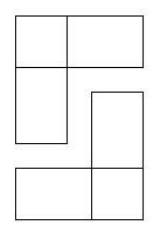

a)
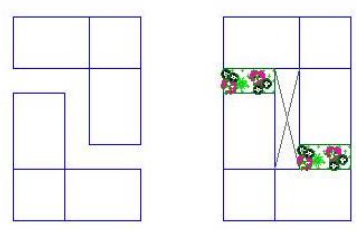

b)

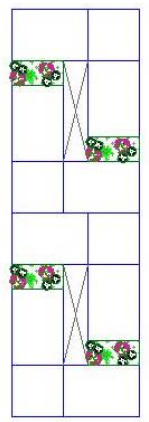

d)

\section{Proposal 5:}

The model is consisting of four units, the two in the middle are 40 foots and the other two are 20 foots. The first floor is consisting of four units 20 foots or two units 40 foots in a perpendicular orientation and in a way of forming two green roofs and two courtyards. Fig. (c) Represents the assembling way for this proposal.

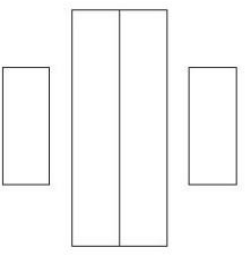

a)

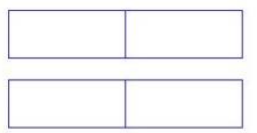

c)

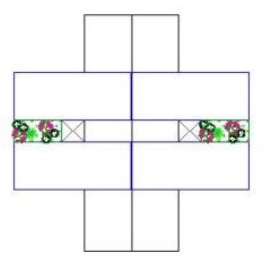

c)

\section{Proposal 6:}

The model is consisting of unlimited number of units overlapping in a perpendicular orientation. The first floor represents the mirror of the ground one in a way of forming continuous green roofs and courtyards. Fig. (c) Represents the assembling way for this proposal.

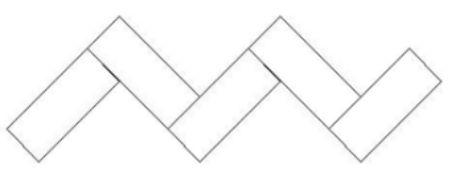

a)

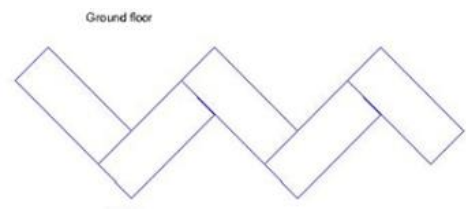

b)

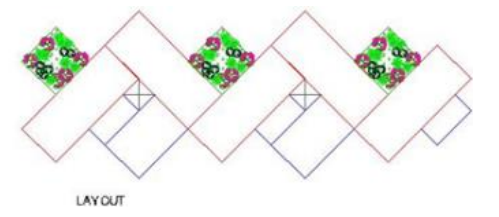

c) 


\section{Conclusions}

Cargotecture is by no means new and several universal projects using shipping containers as building components have been built, used and experienced. As below the paper concludes the following points:

1. Shipping containers could be used as recycled materials, adapted sustainable and green architecture.

2. Although shipping containers are used as a shelters but also it could be used as a vital site in terms of youth camps and holidays, cheap accommodation places, backpacking tourism.

3. Shipping containers could be treated visually reflecting a good urban configuration.

4. Shipping containers could be adapted to stack vertically for many levels and not only in a horizontal way.

5. The paper proposed a design model which could represent a frame work for future studies, as it comes up with different concepts on the level of diagrams, horizontal and vertical configurations.

6. The standards dimensions of ISO shipping containers make them excellent modular units which have the auxiliary ability and plan parameters to deliver a standard accommodation units in an assortment of ways.

7. Cargo buildings, as ordinary structures, can be furnished with green innovations.

\section{Recommendations and Further Studies:}

1. Municipalities in Egypt could select 3 to 4 locations to apply the proposal. Adapting shipping containers in this matter is a multi-use and could be built on the borders of cities every $6 \mathrm{~km}$ or touristic zones or coastal zones where shipping containers units are available, representing a gathering point served by permanent services such as water, electricity and drainage.

2. Students of the departments of architecture and faculties of fine arts in Egypt could develop the proposed design models for wider emphasis on urban configurations.

3. Introduce Cargotecture as competitions on the level of visual image, innovative solutions alternatives, interior design creative such as design of fixed internal furniture units.

\section{References:}

1. 'Shipping Containers as Building Components' J.D.Smith, Msc, University of Brighton, USA, 2006. 
2. Moore, C.M. Yildrim, S.G, Baur, S. W., "Educational Adaptation of Cargo Container Design Features", 2015 ASEE Zone III Conference

3. Elrayies, G. M., "Thermal Performance Assessment of Shipping Container Architecture in Hot and Humid Climates", International Journal on Advanced Science Engineering Information Technology, Vol.7 (2017), No. 4.

4. Radwan, A. H., "Containers Architecture Reusing Shipping Containers in making creative Architectural Spaces” IJSER, Volume 6, Issue 11, November 2015.

5. https://placesjournal.org/article/the-emergence-of-container-urbanism/?cn-reloaded=1 6. Coffman, R., Fithian, L., Akins, E., "Deploying shipping containers for innovative living architecture design education", Journal of Living Architecture, Vol. 4, No. 2, pp: 1-16, 2017. 7. Levinson, Marc. How the Shipping Container Made the World Smaller and the World .Economy Bigger. Princeton University Press

8. https://www.promptus.us/tag/ocean-shipping

9. https://en.wikipedia.org/wiki/Shipping container_architecture

10. Ken Tadashi Oshima, Arata Isozaki (London: Phaidon, 2009), 192-194

12. Kenneth Powell, "Container Architecture," Architect's Journal 223 (May 25, 2006), 31

13. Francis Rambert, Architecture Tomorrow (Paris: Tereil, 2005), 131-132.

14. Quoted in Cathy Lang Ho, "Hold this Site," Architect 99 (June 2010), 36

15. https://environmentalenergetics.com/tag/cargotecture/

16. https://www.seangodsell.com/future-shack

17. https://inhabitat.com/gad-is-a-mobile-shipping-container-gallery-for-traveling-artexhibitons/

18. PSU Center for Real Estate, Urban Development Journal, $4^{\text {th }}$ Quarter 2009, "Sustainable Containers: Cost-Effective Student Housing" Uittenbroek, C., Max, W.

19. /http://www.tempohousing.com/projects/keetwonen

20. https://www.reuters.com/article/us-egypt-container-living/cairo-cargotecturecompany-transforms-shipping-containers-into-homes-idUSKBN17R16K

21. https://progrss.com/design/20161122/qubix-cargotecture-containers-egypt/

22. https://egyptfwd.org/inside-egypts-new-economy-the-cairo-cargotecture-startuppoised-to-rebuild-the-middle-east- $2 /$

23. https://egyptianstreets.com/2017/05/03/egyptian-duo-transform-shipping-containersinto-living-spaces/ 